\title{
Effects of Ionizing Radiations on Germination of Seed and Morphology of Seedlings of Puerto Rican Coffee, Coffea arabica $\mathrm{L}^{1}{ }^{1}$
}

\author{
Tara Singh-Dhaliwal and Anibal Torres-Sepúlveda
}

\section{INTRODUCTION}

Several well-known varieties of Coffea arabica L., such as Caturra, Cera, Maragogipe, and Semperflorens, originated as natural mutants (5). ${ }^{3}$ Therefore, a continuous and intensive search for new beneficial natural coffee mutants is an important phase of our coffee-breeding project (7). However, as the spontaneous mutation rate is extremely low, only a small number of natural mutants has been encountered over a long period of careful search.

It is generally recognized that the mutation rate in plants, as well as in other living organisms, can be greatly increased by ionizing radiations. Consequently the probabilities of obtaining new desirable mutants are also higher.

Since 1957 experiments for producing beneficial mutants through irradiation of seed of Puerto Rican coffee have been in progress. This paper is a brief account of the results of these experiments as they concern the effects of ionizing radiations on the germination of the seed and morphology of their seedlings.

\section{REVIEW OF LITERATURE}

Carvalho (1) and Carvalho, and Antunes Filho and Nogueira (2), on treating seed of several Arabica-type coffee varieties and their hybrids with $\mathrm{X}$-ray doses of 4,200 to $150,000 \mathrm{r}$, found that the seed treated with more than $25,000 \mathrm{r}$ started germination but the young seedlings did not grow further. They also reported that most of the radiation-induced coffee mutants were sterile and had abnormal leaves and branching habits.

1 This investigation was carried on under the Federal-Grant Research Project Hatch 74, Coffee Breeding in Puerto Rico.

2 Associate Plant Breeder and Research Assistant, respectively, Agricultural Experiment Station, University of Puerto Rico, Río Piedras, P.R. The authors are very grateful to Thomas S. Osborne, Associate Scientist, UT-AEC, Agricultural Research Laboratory, Oak Ridge, Tenn., for irradiating the coffee seed lots; to Pedro L. Meléndez, Research Assistant, and other personnel of the Castafier Substation of the Agricultural Experiment Station, University of Puerto Rico, for their cooperation during the course of this investigation, and also to J. Velez-Fortuño Head, Plant Breeding Department, Agricultural Experiment Station, University of Puerto Rico, Rfo Piedras, P.R., for carefully reviewing the manuscript.

8 Italic numbers in parentheses refer to Literature Cited, p. 318. 
Moh and Orbegoso (6), on treating seed from a single tree of Typica variety Coffea arabica with gamma-ray doses of 2,500 to $20,000 \mathrm{r}$, reported that doses of 2,500 to $5,000 \mathrm{r}$ seemed to stimulate plant growth slightly while doses higher than $10,000 \mathrm{r}$ began to inhibit plant growth. They also described several kinds of morphological abnormalities exhibited by the coffee seedlings obtained from irradiated seed.

As recently reviewed by Smith (8) and Desrosier and Rosenstock (3) radiations have been used by many research workers on a large number of plants of economic importance for producing new useful mutants. Consequently, new mutants of commercial value of several crops, such as barley, bean, mustard, pea, peanut, and others, have been produced.

\section{MATERIALS AND METHODS}

Coffee seed used in the present investigation were collected from individual tree selections of Puerto Rican coffee. The moisture contents of szed from different selections generally varied from 14 to 18 percent.

The seed in parchment were treated with different doses of gamma rays and neutrons at the UT-AEC Agricultural Research Laboratory at O.ak Ridge, Tenn.

The seed were sown in loose media in flats under lath shade or in the greenhouse. After several months, when it seemed that all the viable seed had germinated from each treatment, data were collected as to the number of seed germinated, height of seedlings, and general morphological abnormalities exhibited by the seedlings.

The seedlings were planted in a nursery on the ground or in soil-filled plastic bags for up to a year. They were planted in the field under about 50-percent natural shade at the Agricultural Experiment Substation of the University of Puerto Rico, located at Castañer, P.R.

\section{RESULTS}

\section{GERMINATION OF SEED}

Many of the seed lots irradiated with gamma-ray doses of 1,000 to 7,000 $r$ had germination percentages higher, and others lower than those of the corresponding control seed lots. However, all the seed lots irradiated with gamma-ray doses of 8,000 to $20,000 \mathrm{r}$ had relatively lower germination percentages. The decrease in their germination percentages was approximately in direct proportion to the strength of the radiation dose applied. The seed lots irradiated with gamma-ray doses higher than $20,000 \mathrm{r}$ did not germinate.

One of the seed lots irradiated with the neutron dose of 1 hour had a 
3-percent germination. However, all the other seed lots irradiated with the same or higher neutron doses did not germinate.

The coffee selections showed variability as to germination percentages of their control seed lots and those treated with different doses of radiation (table 1).

TABLE 1.-Effect of gamma rays and neutrons on the germination of seed lots of individual tree selections of Puerto Rican coffee, studied at the Agricultural Experiment Station, Rio Piedras, and at the Agricultural Experiment Substation, Casiañer, P.R., 1957-60

\begin{tabular}{|c|c|c|c|c|c|}
\hline \multirow{2}{*}{ Radiation doses } & \multicolumn{5}{|c|}{ Percentage of seed germinated by indicated selections ${ }^{1}$} \\
\hline & $\underset{\text { selection 268 }}{\text { Coffee }}$ & $\begin{array}{c}\text { Coffee } \\
\text { selection 444 }\end{array}$ & $\begin{array}{c}\text { Coffee } \\
\text { selection } 1\end{array}$ & $\mid \begin{array}{c}\text { Coffee } \\
\text { selection } 2\end{array}$ & $\mid \begin{array}{c}\text { Coffee } \\
\text { selection } 5\end{array}$ \\
\hline Control & 62.00 & 74.00 & 26.50 & 41.50 & 44.50 \\
\hline $1,000 \mathrm{r}$ gamma rays $570 \mathrm{r} / \mathrm{minute}$ & 54.00 & 81.00 & - & - & - \\
\hline $2,000 \mathrm{r}$ gamma rays $570 \mathrm{r} / \mathrm{minute}$ & 42.00 & 91.00 & - & - & - \\
\hline $3,000 \mathrm{r}$ gamma rays $570 \mathrm{r} / \mathrm{minute}$ & 78.00 & 89.00 & - & - & - \\
\hline $4,000 \mathrm{r}$ gamma rays $570 \mathrm{r} / \mathrm{minute}$ & 73.00 & 73.00 & - & - & - \\
\hline $5,000 \mathrm{r}$ gamma rays $570 \mathrm{r} / \mathrm{minute}$ & 65.00 & 76.00 & - & - & - \\
\hline $6,000 \mathrm{r}$ gamma rays $570 \mathrm{r} / \mathrm{minute}$ & 65.00 & 79.00 & - & - & - \\
\hline $7,000 \mathrm{r}$ gamma rays $570 \mathrm{r} / \mathrm{minute}$ & 82.00 & 75.00 & - & - & - \\
\hline $8,000 \mathrm{r}$ gamma rays $570 \mathrm{r} /$ minute & 61.00 & 59.00 & - & - & - \\
\hline $9,000 \mathrm{r}$ gamma rays $570 \mathrm{r} / \mathrm{minute}$ & 38.00 & 41.00 & - & - & - \\
\hline $10,000 \mathrm{r}$ gamma rays $570 \mathrm{r} /$ minute & 26.00 & 37.00 & - & - & - \\
\hline $10,000 \mathrm{r}$ gamma rays $721 \mathrm{r} / \mathrm{minute}$ & - & - & 23.00 & 15.00 & 2.00 \\
\hline $20,000 \mathrm{r}$ gamma rays $721 \mathrm{r} /$ minute & - & - & 2.00 & 8.00 & - \\
\hline 30,000 r gamma rays $721 \mathrm{r} /$ minute & - & - & - & - & - \\
\hline $40,000 \mathrm{r}$ gamma rays $721 \mathrm{r} / \mathrm{minute}$ & - & - & - & - & - \\
\hline $50,000 \mathrm{r}$ gamma rays $721 \mathrm{r} / \mathrm{minute}$ & - & - & - & - & - \\
\hline Neutrons, 1 hour & - & - & 3.00 & - & - \\
\hline Neutrons, 2 hours & - & - & - & - & - \\
\hline Neutrons, 3 hours & - & - & - & - & - \\
\hline Neutrons, 4 hours & - & 一 & - & - & - \\
\hline Neutrons, 5 hours & - & - & - & - & - \\
\hline
\end{tabular}

1 Each of the control or untreated seed lots had 200 seed and each of the irradiated seed lots had 100 seed.

\section{HEIGHT OF SEEDLINGS}

The seedlings from the seed lots of P'uerto Rican coffee selection 268, when irradiated with gamma-ray doses of 1,000 to $5,000 \mathrm{r}$ were on the average higher than those from the control seed lot. However, the seedlings of this selection from seed treated with gamma-ray doses of 6,000 to 10,000 $r$ had relatively lower average heights. 
The seedlings from the other Puerto Rican coffee selections, i.e., from seed lots irradiated with gamma rays and neutrons, were relatively lower in average height than the seedlings from the control lots. In general, the decrease in average height of the seedlings was in direct proportion to the strength of the radiation dose applied (table 2).

TABLE 2.-Effect of seed irradialion with gamma rays and neutrons on the height of seedlings of individual tree selections of Puerto Rican coffee studied at the Agricultural Experiment Slation, Rio Piedras, and the Agricullural Experiment Substation, Castañer, P.R., 1957-60

\begin{tabular}{|c|c|c|c|c|c|}
\hline \multirow{2}{*}{ Radiation doses } & \multicolumn{5}{|c|}{$\begin{array}{l}\text { Average height of seedlings of indicated selections in } \\
\text { centimeters }\end{array}$} \\
\hline & $\begin{array}{c}\text { Coffee } \\
\text { selection } 268\end{array}$ & $\underset{\text { selection }+44}{\text { Coffee }}$ & $\left|\begin{array}{c}\text { Coffee } \\
\text { selection } 1\end{array}\right|$ & $\begin{array}{c}\text { Coffee } \\
\text { selection } 2\end{array}$ & $\begin{array}{c}\text { Coffee } \\
\text { selection } 5\end{array}$ \\
\hline Control & 12.81 & 18.34 & 9.66 & 12.54 & 11.09 \\
\hline $1,000 \mathrm{r}$ gamma rays $570 \mathrm{r} /$ minute & 15.93 & 17.14 & - & - & - \\
\hline $2,000 \mathrm{r}$ gamma rays $570 \mathrm{r} / \mathrm{minute}$ & 12.90 & 14.22 & - & - & - \\
\hline $3,000 \mathrm{r}$ gamma rays $570 \mathrm{r} / \mathrm{minute}$ & 15.87 & 15.56 & - & - & - \\
\hline $4,000 \mathrm{r}$ gamma rays $570 \mathrm{r} / \mathrm{minute}$ & 15.26 & 14.03 & - & - & - \\
\hline $5,000 \times$ gamma rays $570 \mathrm{r} / \mathrm{minute}$ & 13.20 & 13.08 & - & - & - \\
\hline $6,000 \mathrm{r}$ gamma rays $570 \mathrm{r} /$ minute & 12.72 & 12.06 & - & - & - \\
\hline $7,000 \mathrm{r}$ gamma rays $570 \mathrm{r} / \mathrm{minute}$ & 12.38 & 12.40 & - & - & - \\
\hline $8,000 \mathrm{r}$ gamma rays $570 \mathrm{r} / \mathrm{minute}$ & 8.98 & 9.86 & - & - & - \\
\hline $9,000 \mathrm{r}$ gamma rays $570 \mathrm{r} / \mathrm{minute}$ & 7.05 & 8.39 & - & - & - \\
\hline $10,000 \mathrm{r}$ gamma rays $570 \mathrm{r} / \mathrm{minute}$ & 6.23 & 5.24 & - & -- & - \\
\hline $10,000 \mathrm{r}$ gamma rays $721 \mathrm{r} / \mathrm{minute}$ & - & - & 7.94 & 10.23 & 4.25 \\
\hline $20,000 \times$ gamma rays $721 \mathrm{r} /$ minute & -- & - & 3.00 & 5.12 & - \\
\hline $30,000 \mathrm{r}$ gamma rays $721 \mathrm{r} / \mathrm{minute}$ & - & - & - & - & - \\
\hline $40,000 \mathrm{r}$ gamma rays $721 \mathrm{r} / \mathrm{minute}$ & - & - & - & - & - \\
\hline $50,000 \mathrm{r}$ gamma rays $721 \mathrm{r} / \mathrm{minute}$ & - & - & - & - & - \\
\hline Neutrons, 1 hour & - & - & 3.83 & - & - \\
\hline Neutrons, 2 hours & - & - & - & - & - \\
\hline Neutrons, 3 hours & - & - & - & - & - \\
\hline Neutrons, 4 hours & - & - & - & - & - \\
\hline Neutrons, 5 hours & - & - & - & - & - \\
\hline
\end{tabular}

\section{GENERAL MORPHOLOGICAL, ABNORMIALITIES}

In the seedling populations from the irradiated seed lots there were seedlings which appeared to be normal and also some which exhibited various kinds and degrees of morphologiral abnormalities. In general, the frequency of abnormal plants and the extent of abnormalities increased in direct proportion to the strength of the radiation dose applied to the seed lots.

Leaf abnormalities, such as redurtion in overall size; narrowing, thickening, and curling of lamina; distorted venation, variegation, chlorosis, and so on, were exhibited by many of the seedlings from irradiated seed. 
Some seedlings from irradiated seed were of extremely reduced height. They had very short internodes and produced very few small-sized primary lateral branches. Some seedlings also exhibited stem fasciation.

A plant of a very reduced size bearing narrow and elongated leaves appeared among the seedlings from a control seed lot. Seedlings similar to it have also often been observed arising from untreated seed lots sown in many other experiments. Morphologically, they resembled many of the abnormal seedlings from irradiated seed (figs. 1 and 2).
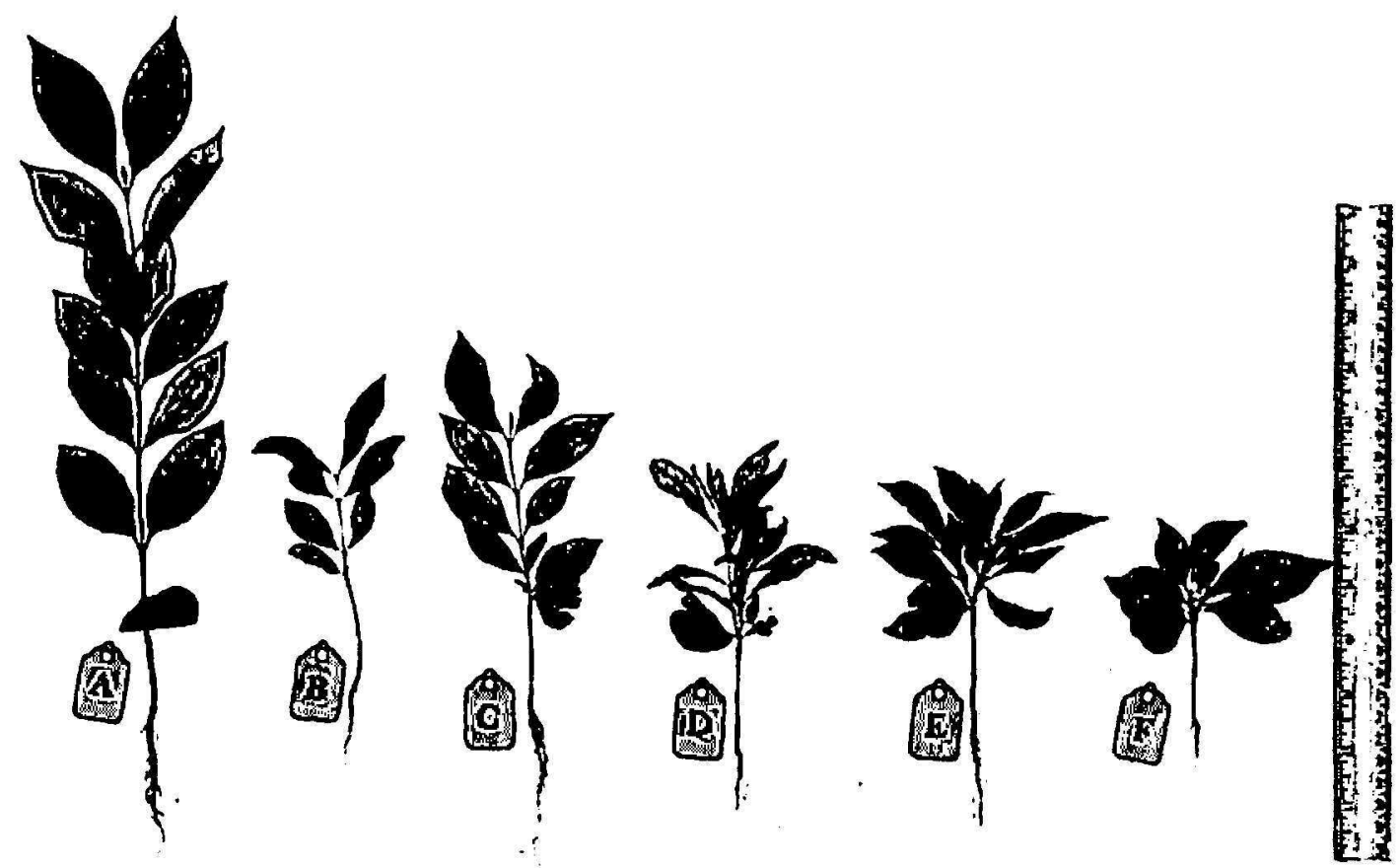

Fig. 1.-Seedlings of Puerto Rican coffee from untreated and treated seed: A, Untreated; B, 5,000 r gamma rays; C, 6,000 r gamma rays; 1), 7,000 r' gamma rays; E, $9,000 \mathrm{r}$ gamma rays; F, 10,000 r gamma rays.

Many of the morphologically abnormal scedlings died before they were 1 year old. However, some of them survived longer. Several of them are growing well in the field and are expected to bear fruit within about a year.

\section{DISCUSSION}

The data on the effects of radiation on germination of coffee seed, height of seedlings, and general morphological abnormalities, show trends similar to those reported by other eoffee research workers $(1,2,6)$.

The results from the irradiation of seed lots of different coffec selections are not auite consistent. This may be because of the differences in their genetic const it ution, moisture content, age, kind of radiation, and so on (4).

Some of the effects of radiation on coffee seedlings seem to be temporaly. 
However, others appear to be of permanent nature, resulting from mutations. Thus it is necessary that the coffee seedlings from irradiated seed be studied up to their maturity to understand the nature of effects of different
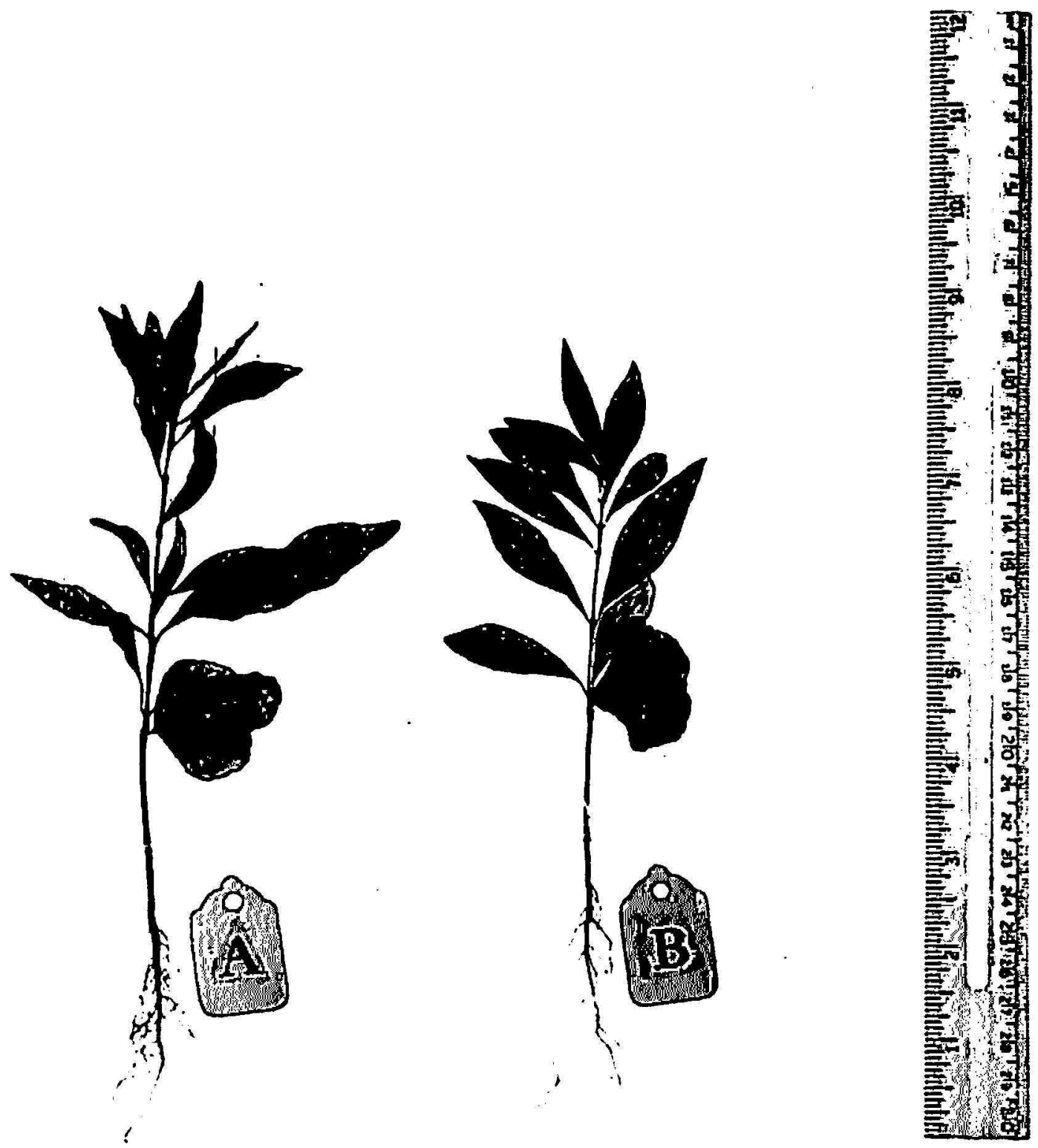

Fig. 2.-Abnormal seedlings of Puerto Rican coffee: A, From seed treated with $7,000 \mathrm{r}$ gamma rays; $\mathrm{B}$, from unt reated seed.

kinds. It will also be necessary to test the seedling progenies of some of the mutants to find out whether the new characters exhibited by them can be transmitted through seed.

In the present investigation all kinds of new coffee mutants are being studied intensively. However, there is special interest in mutants causing alternations or changes in the leaves of the coffee plants.

All the Arabica-type coffee varieties commercially grown in Puerto Rico 
are severely damaged by the leaf miner, Leucoptera coffeella Puer. None of the Arabica-type coffee varieties and selections in our coffee germ-plasm collection is resistant to the leaf miner. However, Coffea stenophylla is immune and $C$. excelsa is highly resistant to the leaf miner. These coffee species have been crossed with Arabica-type coffee varieties and many hybrids are under study. However, interspecific hybridization has many limitations. Therefore, to supplement this approach, it seems justified to screen a large number of Arabica-type coffee seedlings from irradiated seed in order to find possible mutants with leaves like those of $C$. stenophylla and $C$. excelsa, and thus resistant to leaf miner attack. Such coffee mutants might prove very useful for developing Arabica-type coffee varieties resistant to the leaf miner and also otherwise desirable for commercial production in Puerto Rico.

\section{SUMMARY}

Sced lots from five individual tree selections of Puerto Rican coffee, Coffea arabica L., were irradiated with gamma-ray doses of 1,000 to 50,000 $r$, and neutron doses of 1 to 5 hours.

Gamma-ray doses of 1,000 to $7,000 \mathrm{r}$ raised the germination percentages of many of the seed lots and reduced those of others.

Gamma-ray doses of 8,000 to $20,000 \mathrm{r}$ reduced the germination percentages of all the seed lots approximately in direct proportion to the strength of the dose.

Gamma-ray doses higher than 20,000 r completely inhibited the seed germination of all the seed lots.

One of the seed lots had a 3-percent germination when treated with a neutron dose of 1 hour. All the other seed lots treated with neutrons failed to germinate.

Gamma-ray doses of 1,000 to $5,000 \mathrm{r}$ raised, and the higher doses lowered the average heights of the seedlings from the seed lots of Puerto Rican coffee selection 268. However, the radiations reduced the average heights of the seedlings from the seed lots of all other coffee selections in approximately direct proportion to the strength of the dose.

Many seedlings from irradiated seed had abnormal leaves, branches, internodes, and so on. The frequency of abnormal plants and the degree of abnormality generally increased as the strength of the radiation dose increased.

\section{RESUMEN}

Lotes de semilla de cinco selecciones individuales de árboles de café Puerto Rico, Coffea arabica I., se irradiaron con rayos gamma en dósis de 1,000 a $50,000 \mathrm{r}$ y con dósis de neut rones por espacios de 1 a 5 horas.

Las dósis de rayos gamma de 1,000 a 7,000 r subieron los porcentajes de 
germinación de muchos de los lotes de semilla y redujeron los de los restantes.

Las dósis de rayos gamma de 8,000 a 20,000 r redujeron los porcentajes de germinación de todos los lotes de semilla, aproximadamente en proporción directa a la fuerza de las dósis.

Las dósis de rayos gamma en mayor intensidad que de 20,000 r, completamente inhibieron la germinación de todos los lotes de semilla.

Uno de los lotes tratado con una dósis de neutrones por una hora tuvo una germinación de 3 por ciento. Los otros lotes tratados con neutrones no germinaron.

Las dósis de rayos gamma de 1,000 a 5,000 r aumentaron y las de mayor intensidad redujeron el promedio de altura de las plantitas de los lotes de semilla del café Puerto Rico, selección 268. Sin embargo, las radiaciones redujeron el promedio de altura de los lotes de semilla de todas las otras selecciones, aproximadamente en proporción directa a la fuerza de las dósis.

Muchas de las plantitas de semilla irradiada desarrollaron hojas, ramas y entrenudos anormales. La frecuencia de las plantas anormales y los grados de anormalidad generalmente aumentaron cuando se aumentó la fuerza de las radiaciones.

\section{LITERATURE CITED}

1. Carvalho, Alcides, Genetics, Advances in Coffee Production Technology, Coffee and Tea Industries, New York, N.Y., pp. 15-9, 1959.

2. Carvalho, A., Antunes Filho, H., and Nogueira, R. K., Genética de Coffea, XX, Resultados preliminares do tratamento de sementes de café com raios-X, Bragantia 13, nota n* 7, XVII-XX, 1954.

3. Desrosier, Norman W., and Rosenstock, Henry, M., Radiation effects on plants, Radiation Technology in Food, Agriculture, and Biology, the Avi Publishing Co., Inc., Westport, Conn., pp. 230-56, 1960.

4. Konzak, Calvin F., Genetic effects of radiation on higher plants, Quart. Rev. Biol. 32 (1) 27-45, 1957.

5. Krug, C. A., and Carvalho, A., Coffee breeding, Report of the Thirteenth International Horticultural Congress, pp. 1-11, 1952.

6. Moh, C. C., and Orbegoso, G., Effects of ionizing radiations on coffee, Coffee, Turrialba, Costa Rica, 1 (2) 25-30, 1959.

7. Singh Dhaliwal, T., Desarrollo de estirpes o biotipos superiores de café mediante la selección, la hibridación y la propagación asexual, para su cultivo en Puerto Rico, Rev. Agri. P.R. 44 (2) 59-77, 1957.

8. Smith, Harold H, Radiation in the production of useful mutations, Botan. Rev. 24 (1) $1-24,1958$. 